\title{
PENHORABILIDADE DO BEM DE FAMÍLIA VERSUS DIREITO DE MORADIA DO EMPREGADOR: O CASO DOS CRÉDITOS TRABALHISTAS DA TRABALHADORA DOMÉSTICA
}

\author{
Ana Virgínia Moreira Gomes ${ }^{1}$ \\ Késia Rodrigues Costa ${ }^{2}$
}

\begin{abstract}
Resumo
O bem de família é o imóvel cujo proprietário, pessoa ou entidade familiar utiliza com fim residencial. Pretendendo assegurar proteção a esse bem e aos objetos que guarnecem o lar, garantir um mínimo existencial ao indivíduo e possibilitar condições básicas para uma existência digna, a Lei n. 8.009/90 instituiu a cláusula de impenhorabilidade ao bem de família. A Lei n. 8.009/90 previu em seu texto, especificamente, no artigo $3^{\circ}$, um rol de exceções à impenhorabilidade, dentre as quais, a possibilidade da penhora para o pagamento de dívidas trabalhistas do empregador à trabalhadora doméstica. A Lei Complementar - LC n. 150/ 2015 revogou o inciso que estabelecia a exceção em prol da doméstica, sem prever medidas alternativas que assegurem a execução da dívida trabalhista. Como consequência, formou-se uma situação de vulnerabilidade para as trabalhadoras domésticas, pois apesar dos direitos alcançados, não possuem quaisquer garantias quanto à execução de seu crédito salarial. Percebe-se que a LC n. 150/2015 acarretou instabilidade e insegurança ao contrato de trabalho da doméstica. Diante de tais modificações, pretende-se desenvolver a pesquisa científica, com o intuito de refletir acerca da razoabilidade do artigo 46 da LC n. 150/2015, que revoga o inciso "I" do artigo $3^{\circ}$ da Lei n. 8009/90, considerando, assim, alternativas para proteger o crédito salarial dessa trabalhadora. Este é um estudo de caráter teórico-reflexivo, explicativo e descritivo, fundamentado em pesquisa bibliográfica e documental, com consulta a fontes legislativas doutrinárias e jurisprudenciais.
\end{abstract}

Palavras-chave: Bem de Família; Impenhorabilidade; Empregada Doméstica; Verbas Trabalhistas; Direito à Moradia.

\section{INTRODUÇÃO}

Este estudo tem como objetivo refletir acerca da razoabilidade do artigo 46 da Lei Complementar - LC n. 150/2015, que revoga o inciso "I" do artigo 3o da Lei n. 8009/90. O inciso da Lei 8009/90 previa a possibilidade da realização da penhora do bem de família para assegurar o pagamento de dívidas trabalhistas do

\footnotetext{
${ }^{1}$ Doutora em Direito do Trabalho pela Faculdade de Direito - USP. Professora do Programa de Pós-Graduação em Direito Constitucional e do Curso de Direito da Universidade de Fortaleza - UNIFOR. E-mail: avmgomes@gmail.com

${ }^{2}$ Mestranda do Programa de Pós-Graduação em Direito Constitucional - UNIFOR. E-mail: kesiarc@gmail.com.
} 
empregado que exercia atividade no âmbito residencial do empregador. Com essa alteração, garante-se a impenhorabilidade absoluta do imóvel que serve de guarida ao núcleo familiar ou à pessoa que nele habite, embora não integre um grupo familiar.

A LC n. 150/2015 dispõe sobre a relação de trabalho da doméstica ${ }^{3}$ após a promulgação da Emenda Constitucional (EC) no 72/2013, que ampliou o rol de direitos e garantias previstos às empregadas domésticas no parágrafo único do artigo $7^{\circ}$ da Constituição Federal. Apesar de tanto a EC 72/2013 quanto a LC n. 150/2015 ampliarem a proteção legal ao trabalho doméstico, em seu penúltimo artigo - Artigo 46 - a LC n. 150/2015 retira importante proteção para a efetividade dos direitos que prevê, ao excluir a possibilidade da realização da penhora do bem de família na execução de débitos trabalhistas decorrentes do contrato de trabalho doméstico. A racionalidade por trás dessa alteração legislativa é a de que a equiparação de direitos entre a trabalhadora doméstica e os demais trabalhadores urbanos e rurais justificaria igual tratamento no que concerne à impenhorabilidade do bem de família do empregador.

O trabalho doméstico, no entanto, apesar da equiparação de direitos, continua a apresentar características próprias que o diferencia de uma relação de emprego típica, sendo as mais significativas para o objetivo deste estudo não possuir a atividade laboral fins lucrativos e ser exercida no âmbito residencial do empregador. A impossibilidade da penhora do bem de família neste caso pode ensejar um retrocesso na proteção aos direitos até então conquistados por essa categoria trabalhista, uma vez que a execução do empregador que possuísse um único bem restaria frustrada, tendo em vista que o legislador, ao revogar o dispositivo que possibilitava a penhora, não regulamentou medidas alternativas. $\mathrm{O}$ empregador doméstico e o empregador empresa não estão em um mesmo patamar. A satisfação do crédito da empregada doméstica pode depender da penhora do único bem do empregador.

De acordo com o objetivo proposto por esta pesquisa, o artigo investiga mecanismos que propiciem o adimplemento das verbas trabalhistas da trabalhadora doméstica, quando o único bem do empregador é detentor da cláusula de impenhorabilidade. Em tais situações, o estudo propõe ser necessária a ponderação entre os princípios conflitantes no caso: o direito à moradia do devedor e o direito à proteção do crédito salarial do empregado, a partir do princípio da proporcionalidade e de seus subprincípios - adequação, necessidade e proporcionalidade em sentido estrito.

A metodologia utilizada na elaboração do artigo é constituída de estudo de caráter teórico-reflexivo, explicativo e descritivo, fundamentado em pesquisa bibliográfica e documental, com consulta a fontes legislativas doutrinárias e jurisprudenciais. $\mathrm{O}$ artigo desenvolve-se em três tópicos: no tópico 1, será apresentado o instituto

\footnotetext{
${ }^{3}$ Neste estudo, adotar-se-á o termo "trabalhadora doméstica", tendo em vista que mais de $93 \%$ do trabalho doméstico é exercido por mulheres (DIEESE, 2006, p.19).
} 
jurídico do bem de família, suas características e evolução no ordenamento jurídico brasileiro, bem como se busca demonstrar as exceções previstas ao instituto. A análise evidencia a necessidade de proteção ao imóvel por meio da aplicabilidade da cláusula de impenhorabilidade, no objetivo de assegurar o direito fundamental à proteção à moradia digna ao devedor. No tópico 2, examina-se a alteração trazida pela LC n. 150/2015 e as consequências dessa mudança no contrato de trabalho da doméstica.

Por último, o tópico 3 discorre a respeito da colisão dos direitos fundamentais - o direito à moradia do empregador e o direito do trabalhador na proteção de suas verbas salariais - aplicando o teste da proporcionalidade à medida que impossibilita a impenhorabilidade do bem de família do empregador doméstico. Nesta análise, serão consideradas também medidas acessórias que devem ser efetivadas, com o fim de assegurar a proteção à dignidade do trabalhador e coibir o empregador a adimplir suas obrigações trabalhistas. $\mathrm{O}$ estudo propõe que, em razão das características próprias do contrato de trabalho doméstico, há necessidade de previsão legal que assegure a penhora de bens em uma possível execução judicial de créditos trabalhistas.

\section{A PROTEÇÃO AO BEM DE FAMÍLIA E SUA PREVISÃO LEGAL NO ORDENAMENTO JURÍDICO BRASILEIRO}

O instituto jurídico do bem de família consiste na proteção conferida pela norma legal ao imóvel e aos objetos que guarnecem o lar, considerados esses essenciais por proverem o sustento e propiciarem condições mínimas para a sobrevivência do grupo familiar que o utiliza como moradia. Desse modo, pode-se compreender o bem de família ${ }^{4}$ como instrumento necessário para assegurar o respeito à dignidade humana ${ }^{5}$ do indivíduo, de forma a garantir um mínimo existencial para a subsistência familiar (GAMA; MARÇAL, 2014, p. 33-34).

A esses bens, tidos como imprescindíveis à existência do indivíduo, a lei atribui uma cláusula de impenhorabilidade, visando proteger o bem que garante abrigo ao vulnerável e aos seus dependentes de uma possível execução judicial, que estabeleça como pagamento das dívidas por ele contraídas e não quitadas o imóvel que reside.

O bem de família, legal ou voluntário, está intrínseco ao direito fundamental do indivíduo à moradia e, por sua vez, à proteção à dignidade da pessoa humana. Vale aferir que a propriedade do bem de família, por si só,

\footnotetext{
${ }^{4}$ Nomenclatura considerada errônea, pois o bem de família não se restringe ao bem móvel ou imóvel que serve de moradia ou venha contribuir para o sustento da entidade familiar, alcançando também o bem que se investe de igual valor para o indivíduo, que não esteja, porém, integrado a um núcleo familiar (REDONDO; LOJO, 2007, p.123).

${ }^{5}$ A dignidade humana é inerente à pessoa, faz parte do seu próprio ser. Em razão disso, faz do indivíduo detentor de direitos e deveres fundamentais que o amparam e o protegem de situações ofensivas a sua própria existência. Por sua vez, o Estado tem o dever de promover ao ser humano as condições, ainda que mínimas, capazes de assegurar uma vida saudável, sem o submetê-lo a uma situação vexatória e de cunho degradante. Assim sendo, o direito à moradia é uma condição básica ao cidadão (SARLET, 2009, p.67).
} 
não consubstancia o exercício de um direito fundamental autônomo, mas funciona como mecanismo para a concretização do direito fundamental à habitação (CARLI, 2008, p. 116).

O bem de família tem sua origem em uma lei Norte-Americana de 26 de janeiro de 1839, o Homestead Exemption $A c t^{6}$ posteriormente denominada por Lei de Isenção do Local do Lar, por meio da qual se resguardava a pequena propriedade, destinada à moradia ou à produção agrícola, de qualquer penhora judicial.

No Brasil, as Ordenações Filipinas já traziam um breve rol de bens protegidos da penhora, dentre os quais, a casa (SANTOS JUNIOR, 2015). O Código Civil de 1916 protegeu o bem de família, prevendo que para um imóvel ser considerado bem de família seria necessário que o chefe de família - o homem, marido - realizasse previamente o registro do imóvel por meio de instrumento público. Percebe-se que a figura do bem de família estava atribuída unicamente à família formada por homem e mulher. A tutela do bem jurídico do indivíduo que não pertencesse a esse núcleo familiar não estava adstrita à garantia de impenhorabilidade.

A Lei n. 6.015 de 31 de dezembro de 1973 previa que para o bem ser consagrado como impenhorável fazia-se necessária a observância dos requisitos estabelecidos na norma, que requeria a instituição da matrícula do bem no registro de imóveis. O Decreto-Lei n. 3.200/1941 determinou limites ao valor do imóvel a ser considerado bem de família, sendo posteriormente regulamentado pela Lei n. 6.742/79, que excluía a fixação do valor econômico e passou então a reconhecer como bem de família o imóvel cujo proprietário utiliza como residência por mais de dois anos.

A legislação apresentava várias lacunas e entraves em torno da proteção ao bem de família, fazendo necessária a elaboração de uma lei que estabelecesse com maior precisão a proteção à moradia diante de execuções de dívidas judiciais. A conversão da Medida Provisória n. 143 na Lei n. 8.009, de 29 de março de 1990, trouxe uma regulação mais sistemática, ao assegurar a impenhorabilidade ao imóvel que serve de habitação para a entidade familiar ${ }^{7}$, assim como aos bens móveis e utensílios domésticos que compõem o recinto domiciliar ${ }^{8}$. O Código Civil de 2002 passa a regular o tema em seus artigos 1711 a 1722.

\footnotetext{
${ }^{6}$ A Lei do Homestead Exemption Act foi instituída nos EUA, especificamente no Estado do Texas, em 1839, após o país suportar uma grave crise econômica, no período que circunda entre 1837 a 1839, que desestabilizou toda a economia da nação. Nos primórdios de seu desenvolvimento, o país obteve significativo crescimento por meio das atividades agrícolas e comerciárias, fazendo como que inúmeros bancos constituíssem filiais no território. Ocorre que, com o os bancos, houve maior facilidade ao indivíduo e às empresas contraírem empréstimos, com a falsa ideia de obtenção de lucro fácil. $\mathrm{O}$ abuso na contratação de empréstimos e no inadimplemento das obrigações acarretou a falência de milhares de bancos e supostamente deu ensejo a uma profunda crise econômica. Diante da situação que se encontrava o país, pretendendo estimular o povoamento do Estado do Texas, foi criada a Lei do Homestead Exemption Act, que garantia ao proprietário de pequena propriedade a proteção e impenhorabilidade de seu imóvel da execução de dívidas. Posteriormente, o homestead foi imposto em todo o território federal (PIMPÃO, 2010, p. 6-7).

${ }^{7}$ Lei n. 8.009/90: "Art.1 ${ }^{1}$ dispõe que o imóvel residencial próprio do casal, ou da entidade familiar, é impenhorável e não responderá por qualquer tipo de dívida civil, comercial, fiscal, previdenciária ou de outra natureza, contraída pelos cônjuges ou pelos pais ou filhos que sejam seus proprietários e nele residam, salvo nas hipóteses previstas nesta lei. Parágrafo único. A impenhorabilidade compreende o imóvel sobre o qual se assentam a construção, as plantações, as benfeitorias de qualquer natureza e todos os equipamentos, inclusive os de uso profissional, ou móveis que guarnecem a casa, desde que quitados."
} 
A Lei n. 8.009/90 trata especificamente acerca da impenhorabilidade quanto aos bens de família, contudo o Código de Processo Civil, em seu artigo 649, enumera taxativamente os bens considerados absolutamente impenhoráveis, dentre os quais: títulos, vestuários, fundo de poupança, seguro de vida, dentre outros, expressos no rol do dispositivo.

O Superior Tribunal de Justiça, pretendendo dirimir dúvidas em torno de quem possa identificar-se como proprietário do bem de família, publicou o Enunciado n. 364, estendendo o conceito de impenhorabilidade de bem de família a todas as pessoas solteiras, separadas e viúvas que possuem um imóvel como moradia. Assim, ao contrário do que previa o Código Civil de 1916, passa-se a reconhecer a impenhorabilidade do imóvel do indivíduo que não integra um grupo familiar, porém habita o seu bem com ânimo definitivo, com a intenção de ali fixar seu domicílio.

Ademais, importante destacar que a Súmula n. 486 do STJ garante proteção ao único imóvel residencial do devedor, ainda que não seja seu lugar de moradia, estando locado a terceiros, desde que a renda por ele obtida seja meio a propiciar a sua subsistência ou a moradia da sua família. Percebe-se que o Tribunal não somente amplia o conceito de quem é detentor do bem de família, como também amplia o próprio conceito de bem de família, que passa a abranger, além do imóvel em que o indivíduo reside, o imóvel que, alugado, seja meio de sustento do seu proprietário e daqueles que dele dependem. Nessas situações, o bem passa a ser garantido pela cláusula de impenhorabilidade.

Ressalta-se ainda que os veículos de transporte, obras de artes e adornos suntuosos ${ }^{9}$ não são bens impenhoráveis, porém, sendo o veículo instrumento que viabiliza o exercício do trabalho, poder-se-ia considerá-lo como meio essencial para obter o sustento da família, sendo, assim, impenhorável (HONÓRIO, 2008, p. 30).

Da análise legislativa, depreende-se que o bem de família pode ser estabelecido de dois modos: voluntário ou convencional e legal ou involuntário. O bem de família voluntário, previsto no artigo 1.711 do Código Civil de 2002, ${ }^{10}$ advém do Código Civil de 1916. Nesse caso, o bem de família é aquele em que o indivíduo ou a entidade familiar desprende de seu patrimônio e o designa por meio de instrumento público específico. O indivíduo ou grupo familiar que possui mais de um bem residencial e deseja investir um dos bens com a cláusula de impenhorabilidade deve instituí-lo previamente para ser possível sua identificação como bem de

\footnotetext{
${ }^{8}$ Lei n. 8.009/90: "Art. 2 Excluem-se da impenhorabilidade os veículos de transporte, obras de arte e adornos suntuosos. Parágrafo único. No caso de imóvel locado, a impenhorabilidade aplica-se aos bens móveis quitados que guarneçam a residência e que sejam de propriedade do locatário, observado o disposto neste artigo."

${ }^{9}$ A impenhorabilidade irá recair sobre o imóvel que serve de moradia ao devedor e sua família, seja ele urbano ou rural. Portanto, os imóveis comerciais e industriais, ou mesmo aqueles que possam ser objeto de habitação, mas ainda não o são, não se encontram dentro das disposições legais que assegurem sua impenhorabilidade (CZAJKOWSKI, p.44, 1994).

${ }^{10}$ Art. 1.711. Podem os cônjuges, ou a entidade familiar, mediante escritura pública ou testamento, destinar parte de seu patrimônio para instituir bem de família, desde que não ultrapasse um terço do patrimônio líquido existente ao tempo da instituição, mantidas as regras sobre a impenhorabilidade do imóvel residencial estabelecida em lei especial.
} 
família.

Já o bem legal ou involuntário é previsto no artigo $1^{\circ}$ da Lei n. 8.009/90 e decorre da tutela conferida pela norma legal que estabelece como impenhorável o bem do casal ou da entidade familiar. O bem de família legal independe da instituição e da vontade dos interessados; a lei por si só garante a proteção ao bem, móvel ou imóvel, que, sendo móvel, deve encontrar-se quitado, e sendo imóvel, que seja utilizado como residência.

Ao atribuir a cláusula de impenhorabilidade ao bem de família, a lei se assenta no conflito entre o direito do devedor a uma moradia digna e o direito do credor de receber o pagamento. Por meio da expropriação do bem imóvel, tenta-se impedir que os processos executórios tornem-se ineficazes e que a busca pela justiça seja considerada inútil e descabida, por não apresentar respostas àquele que pleiteia a tutela de seus direitos.

A não execução da dívida acarreta a frustração do exequente e provoca a instabilidade jurídica (TOALDO; SAUTHIER, 2014, p. 13). A penhora é o meio judicial que permite ao exequente alcançar o bem do devedor, com o fim de receber o pagamento do crédito em mora. A impenhorabilidade, no entanto, com o intuito de preservar um mínimo necessário para a defesa da dignidade humana, fixa limites ao poder do Estado de tocar no patrimônio de alguns bens do devedor - como é o caso do bem de família - para executar dívidas de sua titularidade. (REDONDO; LOGO, 2007, p. 36-80).

Ao optar por garantir a proteção a uma vida digna e resguardar o direito do devedor a uma moradia digna, a lei restringe o direito do credor em ter adimplida a obrigação pecuniária que foi assumida pelo devedor e, eventualmente, restringindo as condições de subsistência do próprio credor.

A penhora emerge da ação do devedor em descumprir a responsabilidade contratual que firmou com o credor. Assim sendo, uma vez constituída uma obrigação entre esses sujeitos, nasce para um o direito de receber e, ao outro, o dever de cumprir financeiramente com o que se comprometeu a realizar. Do inadimplemento da dívida, advém o direito do credor em executar judicialmente o devedor, com o fim de coibi-lo, por meio da penhora de bens, a realizar o pagamento do débito em que incorreu.

Reconhecendo a necessidade de proteção ao credor em situações nas quais o não adimplemento da obrigação pecuniária pode representar uma ameaça à sua subsistência ou de sua família, o legislador estabeleceu no Artigo $3^{\circ}$ da Lei n. 8.009/90 um rol taxativo de exceções à impenhorabilidade do imóvel familiar:

Art. 3० A impenhorabilidade é oponível em qualquer processo de execução civil, fiscal, previdenciária, trabalhista ou de outra natureza, salvo se movido:

I - (Revogado pela Lei Complementar no 150, de 2015)

II - pelo titular do crédito decorrente do financiamento destinado à construção ou à aquisição do imóvel, no limite dos créditos e acréscimos constituídos em função do respectivo contrato;

III - pelo credor da pensão alimentícia, resguardados os direitos, sobre o bem, do seu coproprietário que, com o devedor, integre união estável ou conjugal, observadas as hipóteses em que ambos responderão pela dívida;

IV - para cobrança de impostos, predial ou territorial, taxas e contribuições devidas em 
função do imóvel familiar;

$\mathrm{V}$ - para execução de hipoteca sobre o imóvel oferecido como garantia real pelo casal ou pela entidade familiar;

VI - por ter sido adquirido com produto de crime ou para execução de sentença penal condenatória a ressarcimento, indenização ou perdimento de bens.

VII - por obrigação decorrente de fiança concedida em contrato de locação. (BRASIL, 1990).

Da análise do dispositivo, é possível traçar algumas considerações. Primeiro, o inciso "VII” não constava da redação originária do texto, foi instituído pela Lei n. 8.245/91, que dispõe acerca da locação de imóveis urbanos. O STJ consolidou entendimento acerca da possibilidade de realizar a penhora do bem de família quando seu proprietário for fiador em um contrato de locação de imóvel.

O inciso "III" teve sua redação original, que anteriormente previa a possibilidade da penhora do bem de família em dívida de pensão alimentícia, protegendo os direitos do alimentado, alterada pela Lei n. 13.144, de 6 de julho de 2015. O texto atual resguarda o proprietário do imóvel, que não seja o devedor, de possível constrição judicial, de modo que o alimentado somente poderá requerer a penhora de parte do imóvel correspondente ao quinhão da propriedade do alimentante.

Por fim, o inciso I foi revogado pela Lei Complementar - LC n. 150, de $1^{\circ}$ de junho de 2015, que regulamenta as novas disposições que regem o contrato da empregada doméstica, decorrente da Emenda Constitucional 72 de 2013. A redação original da Lei n. 8.009/90 previa a possibilidade da penhora do bem de família em razão dos créditos trabalhistas e previdenciários de empregadas domésticas. O empregador doméstico que não assegurasse à trabalhadora o recebimento das verbas trabalhistas poderia ser judicialmente executado e ter seu único bem concedido, como meio de adimplir o pagamento da dívida trabalhista ou previdenciária. ${ }^{11}$

O inciso I, que previa a exceção à cláusula de impenhorabilidade no caso de dívidas trabalhistas e previdenciárias decorrentes do emprego doméstico, foi expressamente revogado pela LC n. 150, tornando impenhorável o bem de família por execução de dívida trabalhista ou previdenciária do empregador doméstico. A LC n. 150, no entanto, resumiu-se a revogar o inciso I, não dispondo sobre qual o mecanismo aplicável na execução judicial para assegurar à trabalhadora doméstica o recebimento dos direitos trabalhistas devidos por seu empregador.

Considerando a ratio legis do Artigo $3^{\circ}$ da Lei 8.009/90, qual seja, proteger o credor em casos nos quais o adimplemento da dívida é necessário para sua subsistência, ao revogar o Inciso I, a LC n. 150 cria uma lacuna, uma vez que o não pagamento dos créditos trabalhistas e previdenciários pode representar uma ameaça à subsistência da trabalhadora doméstica ou de sua família, em especial por não se tratar o empregador de uma empresa com outros bens disponíveis para execução. Dada essa peculiaridade do trabalho doméstico, a impenhorabilidade do bem de família do empregador doméstico acaba por constituir um ônus não razoável a ser 
suportado pelas trabalhadoras domésticas.

Pelo exposto, é relevante realizar um estudo acerca das inovações advindas da ampliação do rol de direitos ao trabalhador doméstico, a fim de identificar os seus reflexos na execução judicial e os instrumentos possíveis para garantir a observância desses direitos.

\section{O TRABALHO DOMÉSTICO NO BRASIL E AS INOVAÇÕES ADVINDAS DA LEI COMPLEMENTAR N. $150 / 15$}

O trabalho doméstico é a atividade desenvolvida de forma contínua, onerosa e pessoal, sem fins lucrativos, à pessoa ou entidade familiar, no âmbito domiciliar dessas, por mais de dois dias por semana ${ }^{12}$. Tipo de trabalho realizado por uma trabalhadora em ou para uma residência particular (Convenção 189 da Organização Internacional do Trabalho - OIT, Artigo $1^{\circ}$ ), o trabalho doméstico é realizado em sua maioria por mulheres, migrantes, por grupos raciais específicos e, em geral, por trabalhadoras com baixo nível educacional e pouca qualificação profissional (ILO, 2013). A atipicidade do local de trabalho (residência particular) e das condições de trabalho (por exemplo, o trabalho é realizado de modo isolado de outros trabalhadores), somada ao baixo reconhecimento social e econômico, tornaram o trabalho doméstico uma das mais vulneráveis formas de trabalho (Cf. SMITH, 2011; NEETHA; PALRIWALA, 2011).

A trabalhadora doméstica, por muito tempo, foi sujeita à desigualdade, opressão e ao preconceito, em especial em razão da ausência de proteção ao seu trabalho. Ironicamente, as mesmas características que contribuem para a vulnerabilidade do trabalho doméstico foram usadas como motivos para que o Direito do Trabalho, tanto no âmbito internacional, quanto nacional, excluísse as trabalhadoras domésticas da proteção legal garantida a trabalhadores em fábricas, lojas, escritórios (BLACKETT, 2012; RAMIREZ-MACHADO, 2003).

No Brasil, o processo de regulamentação do trabalho doméstico começou no início do século passado, com a regulação provincial relativa à definição de trabalhadores domésticos e sua identificação legal através da introdução de um cartão de trabalho. Esses regulamentos não visavam reconhecer os direitos trabalhistas dessas trabalhadoras, mas sim estabelecer um sistema de controle das trabalhadoras domésticas, principalmente por razões sanitárias e criminais (BERNARDINO-COSTA, 2007).

A Consolidação das Leis Trabalhistas, promulgada pelo Decreto-Lei n. 5452, de 10 de novembro de 1943, excluiu de sua proteção o trabalho doméstico. Assim sendo, poder-se-ia compreender que os trabalhadores que exercessem atividades de cunho lucrativo seriam então amparados por essa norma, enquanto que o trabalho das empregadas domésticas deveria ser regulamentado em legislação específica, o que ocorreu muito tempo

\footnotetext{
${ }^{11}$ Súmula 368 TST.

${ }^{12}$ Artigo $1^{\circ}$ da Lei Complementar n. 150/2015.
} 
depois da promulgação da CLT. Enquanto as primeiras leis trabalhistas e a CLT excluíam o trabalho doméstico de sua regulação, em 1960, a Lei n. 3807, pela primeira vez, garantiu um direito especial às trabalhadoras domésticas - reconhecendo essas trabalhadoras como contribuintes voluntárias no sistema de segurança social. Somente em 11 de dezembro de 1972, com a promulgação da Lei n. 5.859, a categoria foi regulamentada e teve assegurados alguns direitos trabalhistas.

Em 1988, a Constituição Federal, no parágrafo único do seu artigo 7º, regulou um rol de direitos previstos especificamente à trabalhadora doméstica, quais sejam: salário-mínimo, fixado em lei, nacionalmente unificado, capaz de atender às suas necessidades vitais básicas e às de sua família, com moradia, alimentação, educação, saúde, lazer, vestuário, higiene, transporte e previdência social, com reajustes periódicos que the preservem o poder aquisitivo, sendo vedada sua vinculação para qualquer fim, irredutibilidade salarial, salvo o disposto em convenção ou acordo coletivo, décimo terceiro salário, repouso semanal remunerado, preferencialmente aos domingos, gozo de férias anuais remuneradas com, pelo menos, um terço a mais do que o salário normal, licença à gestante, sem prejuízo do emprego e do salário, com a duração de 120 dias, licença paternidade, aviso prévio proporcional ao tempo de serviço, no mínimo de 30 dias nos termos da lei, aposentadoria e a integração à Previdência Social.

O trabalho doméstico vem sendo crescentemente objeto de proteção legal, no entanto, ainda persistem o preconceito e o não reconhecimento de direitos em comparação aos demais trabalhadores, resultando em profunda desigualdade e desrespeito à dignidade dessas trabalhadoras. A OIT e a maioria de seus Estados membros historicamente excluíram trabalhadoras domésticas da proteção do direito do trabalho ou editaram leis especiais que reconheciam menos direitos que aqueles conferidos aos trabalhadores típicos (SMITH, 2007; DIAZ-ORDAZ, 2010/2011). A falta da proteção legal foi elemento decisivo para a vulnerabilidade desse tipo de trabalho, marcado por altos índices de informalidade e pela constante violação de direitos humanos e fundamentais do trabalho (MANTOUVALOU, 2012).

Recentemente, um avanço histórico foi alcançado pela OIT na direção da maior proteção ao trabalho doméstico. Em 2011, foi aprovado pela Conferência Internacional do Trabalho da OIT o primeiro tratado internacional sobre trabalho doméstico: a Convenção 189, reconhecendo a essas trabalhadoras o direito a condições justas de trabalho e a direitos humanos e fundamentais do trabalho. A Convenção 189, aprovada em 16 de junho de 2011 pela Conferência Internacional do Trabalho da OIT e em vigor desde 5 de setembro de 2013, foi recebida como um tratado histórico e inovador. A Convenção, junto com a Recomendação 201, garante às trabalhadoras domésticas de forma completa proteção legal extremamente necessária (MANTOUVALOU; ALBIN, 2012). A mensagem da Convenção 189 é clara: as trabalhadoras domésticas, como os demais trabalhadores, têm direito a condições de trabalho decentes e justas (ILO, 2011). A Convenção se utiliza de uma 
dupla estratégia de regulação: por um lado, garante às trabalhadoras domésticas o mesmo nível de proteção legal que aquele assegurado ao empregado típico; por outro, considera as características e necessidades específicas do trabalho doméstico, reconhecendo a necessidade de disposições especiais no que concerne a certas condições de trabalho. ${ }^{13}$

O Brasil, apesar de ser Estado-membro da OIT, ainda não ratificou a Convenção n. 189. O país segue, no entanto, concretizando o ideal, previsto na Convenção n. 189 e, no âmbito interno, pela Constituição Federal de 1988, de estabelecer a igualdade de direitos trabalhistas entre trabalhadoras domésticas e o trabalhador típico. Nesse sentido, a Emenda Constitucional n. 72, de 2 de abril de 2013, veio ampliar o rol de direitos e garantias fundamentais do trabalho assegurados às trabalhadoras domésticas, garantindo o mesmo nível de proteção legal que aquele assegurado ao empregado típico.

A EC n. $72 / 13$ alterou o parágrafo único do artigo $7{ }^{\circ}$ da $\mathrm{CF} / 88$, estendendo aos trabalhadores domésticos os direitos e as garantias asseguradas aos trabalhadores urbanos e rurais. Para regulamentar a aplicação dos novos direitos fundamentais da trabalhadora doméstica, foi promulgada a Lei Complementar n. 150, de $1^{\circ}$ de junho de 2015, que revoga o inteiro teor da Lei n. 5859/72, passando a partir de então a regulamentar as disposições que regem o contrato de trabalho da empregada doméstica.

Dentre os dispositivos da lei, conforme já delineado no tópico anterior, a LC n. 150/15 altera também a Lei n. 8.009/90, tornando impenhorável o bem de família para pagamento de dívidas trabalhistas com o empregado que exerce atividade dentro da casa do empregador, com o fim de preservar o direito à moradia e o mínimo existencial do devedor. Nesse aspecto, a LC apresenta-se desproporcional e incongruente com o ideal que busca proteger, pois, ao estender o rol de direitos, retrocede em excluir medidas que visavam possibilitar a execução das verbas trabalhistas e previdenciárias à empregada doméstica, sem identificar o mecanismo a ser instituído para assegurar o respeito e observância aos novos direitos, bem como a coibir o empregador de praticar infrações à legislação trabalhista.

Entendeu o legislador que a ampliação dos direitos trabalhistas concedidos à empregada doméstica por meio da EC n. 72/2013 colocou essas trabalhadoras em uma posição de igualdade com os trabalhadores urbanos e rurais. É certo dizer que os novos direitos conquistados pela trabalhadora doméstica conferiram maior reconhecimento na luta pelo respeito da sua dignidade humana. Entretanto, a LC n. 150 desconsiderou as peculiaridades do trabalho doméstico, ignorando a necessidade de disposições especiais para esse trabalho, em especial, no que concerne à efetivação de direito em razão, dentre outros fatores, do isolamento da trabalhadora doméstica, da ausência de organização coletiva, do baixo nível educacional, da alta informalidade, do baixo nível de renda.

\footnotetext{
${ }^{13}$ Como por exemplo, saúde e segurança no trabalho, seguridade social, jornada de trabalho e fiscalização do trabalho.
} 
A atividade da trabalhadora doméstica ocorre no âmbito residencial do seu empregador, o que provoca uma fragilidade maior em sua relação de emprego, tendo em vista os entraves à fiscalização e a relação de familiaridade, que falsamente se impõe à empregada pelo empregador, por vezes, na intenção de desvencilhar-se das obrigações trabalhistas. Assim, embora os direitos advindos com a promulgação da EC n.72/2013 tenham propiciado às trabalhadoras domésticas melhores garantias, tal fato, por si só, não as equipara ao trabalhador típico. Mesmo com a equiparação de direitos, o local de trabalho da empregada doméstica não é um estabelecimento comercial e disso decorrem dificuldades para a efetivação de seus direitos, dentre as quais, obstáculos à fiscalização do trabalho e à execução de seus créditos trabalhistas.

Não pode a empregada doméstica, por exemplo, pleitear à justiça a penhora de objetos, ferramentas, carros e utensílios que somente uma empresa teria para a satisfação do seu crédito. É por estar inserido em uma circunstância incomum que se fazem necessárias regras especiais para o trabalho doméstico, que tratem de regulamentar cada condição distintiva da categoria e de assegurar a observância de seus direitos. Essa é a dupla estratégia regulatória da Convenção 189, ignorada pela LC 150, qual seja: garantir às trabalhadoras domésticas o mesmo nível de proteção legal que aquele assegurado ao empregado típico; e considerar as características e necessidades específicas do trabalho doméstico, reconhecendo a necessidade de disposições especiais para esse trabalho.

Nesse sentido, a impenhorabilidade do bem de família inviabiliza a execução de dívidas trabalhistas, pois qual seria a medida estabelecida pela lei para persuadir o empregador, ora executado, a adimplir o pagamento dos créditos trabalhistas, quando o bem de família é o único bem disponível? A execução tem por objeto a satisfação de um direito do trabalhador, por meio do pagamento de uma prestação que lhe é devida, podendo ocorrer de forma voluntária, sem a necessidade de medidas judiciais, ou forçada, quando o cumprimento da obrigação, que se encontra em atraso, decorre de uma determinação judicial (DIDIER JR et al., 2011, p. 28). A penhora do bem de família é medida executória excepcional, somente aplicável após incessantes tentativas, judiciais e extrajudiciais, de fazer com que o empregador quite a dívida com o trabalhador. Compreende-se que a penhora tem o poder de constranger o empregador e instigá-lo a cumprir a obrigação inadimplente.

O empregador que conhecesse o risco de perder o seu único imóvel em razão de débitos trabalhistas seria mais cauteloso e buscaria com maior esforço realizar o pagamento das verbas trabalhistas, enquanto o empregador que sabe da existência do débito, possuidor de um único bem, que, por sua vez, está protegido pela impenhorabilidade, não despenderá o mesmo esforço, pois tem por certo que nada poderá ocorrer. A LC n. 150, ao revogar a regra de exceção dos créditos trabalhistas e previdenciários da trabalhadora doméstica, gera frustração pela ineficácia processual, ao desamparar o credor do único meio para a satisfação do seu crédito. 
É importante que, a fim de concretizar o próprio objetivo a que se presta a LC n. 150, o legislador venha suprir as lacunas deixadas por essa norma, prevendo mecanismos que assegurem a execução da dívida trabalhista, pois, nos moldes que se encontra a legislação, seria mais benéfico ao empregador não cumprir a lei do que cumprila. Ora, qual seria o ônus suportado pelo empregador que demonstra em juízo a existência de um único bem e manifesta-se insuficiente de condições econômicas para arcar com as dívidas oriundas do contrato? Não haveria nenhum prejuízo a ele, e o processo seria apenas mais um nas prateleiras dos fóruns judiciais. ${ }^{14}$

Além do que, cumpre questionar que estímulo teria o empregador que cumpre suas obrigações corretamente, suportando os ônus de um contrato trabalhista, em continuar com tal conduta, se o seu semelhante que em nada colaborou com a justiça cometeu diversas infrações trabalhistas e não teve quaisquer prejuízos em razão de seus atos? O empregador é impulsionado a cumprir a lei em razão do alto valor da sanção em caso de descumprimento da norma e do elevado risco de ser flagrado cometendo a infração; assim, prefere obedecê-la e arcar com o custo trabalhista, por considerar que o prejuízo por não cumprir é maior do que o ônus por cumpri-la, preferindo não se submeter ao risco (CARDOSO; LAGE, 2007, p. 72). Todavia, sendo o ônus por não cumprir a legislação menor que aquele suportado por quem a cumpre, certamente o empregador preferirá o risco de não respeitar o dispositivo legal, acarretando severos danos ao trabalhador.

Por ser a atividade doméstica desenvolvida em situação diversa das demais, a medida mais razoável seria estabelecer mecanismos especiais, de acordo com as características da categoria trabalhista, em que levasse em consideração não somente o direito de moradia do devedor, mas que considerasse a natureza salarial do crédito trabalhista do empregado e seu caráter alimentar, imprescindível para a subsistência do trabalhador, ora credor, e de seus dependentes.

A modificação advinda da Lei Complementar n. 150/15 no tocante à impenhorabilidade do bem de família para a execução de dívidas trabalhistas trouxe mais desvantagens do que benefícios ao empregado doméstico, tendo em vista que acarretou uma insegurança quanto à satisfação de seu crédito.

A execução seria possível com a penhora de outros bens que não fosse o bem de família, porém facilmente o empregador poderia ludibriar a busca judicial. No momento da aquisição de um bem, por exemplo, o empregador, prevendo possíveis execuções judiciais, poderia, por meio de uma fraude contra seus credores, estabelecer falsamente que a propriedade do bem pertenceria a um terceiro, quando de fato seria o empregador o próprio detentor, ainda que de "fachada", dificilmente o empregado doméstico, como parte hipossuficiente, teria meios para comprovar a infração.

\footnotetext{
${ }^{14}$ Existe no Brasil um sistema denominado Banco Nacional de Devedores Trabalhistas-BNDT, onde se encontram inseridos os dados dos empregadores condenados em sentença judicial trabalhista ou que tenham celebrado acordo e sido insolventes, contudo tal medida não se apresenta eficiente para inibir o empregador doméstico do inadimplemento de suas obrigações trabalhistas. $\mathrm{O}$ tópico 3 do presente trabalho tratará acerca do assunto com maior afinco.
} 
A impenhorabilidade do bem de família na execução do crédito trabalhista significa um retrocesso - o que é vedado - nas garantias legais à trabalhadora doméstica, já tão discriminada e penalizada ao longo do tempo. O princípio da proibição do retrocesso social estabelece que uma vez assegurada legalmente uma prestação ao indivíduo, não poderá o legislador dela dispor, sem apresentar alternativa que a substitua. Ainda que o direito previsto não constitua a ideia de realizar uma evolução, proíbe-se retroceder (QUEIROZ, 2006, p. 67-68).

A consolidação de um direito fundamental ao trabalhador modifica a sua natureza de direito prestacional, passando a constituir um direito de defesa, possibilitando ao indivíduo detentor da proteção legal pleitear o amparo judicial sempre que vislumbrar uma ação legislativa que pretenda desrespeitar o direito por ela estabelecido, uma vez que se encontra concretizado (JÚNIOR, 2006, p. 170). Nesse caso, a LC n. 150 constitui uma regulamentação em que o próprio legislador afronta um direito à proteção do trabalhador, sem estabelecer nenhuma compensação, pois a penhora seria medida que viabilizaria a proteção ao crédito salarial do empregado, garantindo assim a observância da norma legal.

Por fim, o serviço desempenhado por uma empregada doméstica é importante ao auxílio das atividades do lar, porém não é imprescindível para a sobrevivência daquela família ou do indivíduo. Assim sendo, uma vez que se decide por sua contratação, dever-se-ia atentar para todos os benefícios e ônus que o contrato de trabalho pode acarretar, pois, como os demais trabalhadores, a empregada doméstica é detentora de direitos e garantias, as quais the devem ser plenamente assegurados.

Ao revogar o Inciso I do Artigo $3^{\circ}$ da Lei n. 8.009/90, a LC n. 150 buscou assegurar condições mínimas de moradia e o respeito à dignidade humana do devedor; entretanto, o legislador não atentou para a afronta ao direito e proteção do trabalhador de ter a satisfação de seu crédito, de natureza salarial e alimentícia. Faz-se necessária a resolução desse conflito a partir de um raciocínio de ponderação pela aplicação do princípio da proporcionalidade.

\section{A RELATIVIZAÇÃO DA PENHORA A LUZ DA PROPORCIONALIDADE COMO INSTRUMENTO HÁBIL A GARANTIR O CRÉDITO DO TRABALHADOR}

Ao analisar a penhorabilidade do bem de família como medida processual a ser aplicada na execução do crédito do trabalhador doméstico em detrimento da insolvência do empregador, observa-se a colisão entre dois princípios fundamentais, quais sejam, o direito à moradia do empregador e o direito à proteção do trabalhador.

A Constituição Federal de 1988 incluiu o direito à moradia no rol do artigo 6º que o prevê como direito social fundamental ao indivíduo, estando intrinsecamente relacionado à dignidade e proteção da pessoa humana, no que concerne à garantia de condições existenciais mínimas para assegurar uma vida digna. Reputa-se que o 
indivíduo que não possui um lugar que lhe proporcione bem-estar e forneça guarida a ele e a seus dependentes não terá respeitada a sua dignidade (SARLET, 2003, p. 209).

Para Pimpão (2010, p. 15), não basta que se tenha um teto para morar, necessário verificar as circunstâncias físicas em que aquele bem se encontra, observando se é compatível ao desenvolvimento pleno da pessoa. Deve-se, portanto, primar em propiciar ao indivíduo meios materiais mínimos, imprescindíveis à sua existência.

Ao impor ao devedor a satisfação de uma obrigação que não possui meios para suportar, em razão de sua excessiva onerosidade, o direito atrai para a sociedade o dever de arcar com as consequências desse ato, uma vez que o devedor que perde seu único bem para a quitação de suas dívidas insere-se em uma situação de penúria, recorrendo a partir de então às filas assistenciais do Estado; quando não, será encontrado nas ruas, em busca de um "teto" que lhe ofereça proteção (MARCO; BRANCO, 2014, p. 343).

Assim como o direito à moradia, assegurado constitucionalmente e protegido pela impenhorabilidade, $\mathrm{o}$ artigo $7^{\circ}$ da $\mathrm{CF} / 88$ elenca um rol de direitos atribuídos aos trabalhadores urbanos e rurais e prevê: salário mínimo, décimo terceiro salário, fundo de garantia por tempo de serviço, multa indenizatória por demissão sem justa causa, férias acrescidas de $1 / 3$, entre outras garantias previstas em prol do empregado.

Contudo, não observando o empregador as normas trabalhistas, será pleiteado judicialmente para a realização do pagamento das verbas devidas. O conjunto das verbas rescisórias, indenizatórias e remuneratórias decorrentes da relação de emprego possui caráter alimentar, tendo em vista destinar-se ao sustento do trabalhador e de seus dependentes. É por meio do trabalho que o obreiro aufere sua renda e provém seu alimento (MUNIZ, 2009, p. 68).

No que concerne especificamente ao salário, corresponde ao pagamento realizado pelo empregador ao empregado, em razão do contrato firmado e da relação de emprego que se desenvolve entre eles. $\mathrm{O}$ artigo 76 da Consolidação das Leis Trabalhistas prevê que o salário está designado a satisfazer as necessidades mínimas de alimentação, vestuário, higiene, habitação e transporte. O salário é determinado não só ao indivíduo, mas se estende à proteção e ao sustento de toda a família, conforme dispõe o inciso "IV" do artigo 70 da CF/88. Posto isso, verifica-se a essencialidade em garantir à empregada doméstica a satisfação de seu crédito salarial.

A impenhorabilidade do bem de família inviabiliza a execução da dívida e, portanto, acarreta um afronto à dignidade do trabalhador, princípio que se busca tutelar. $\mathrm{O}$ empregado que exerce sua atividade sem receber pelo serviço prestado assemelha-se à figura de um escravo, refletindo mais uma vez sobre a empregada doméstica a desigualdade e o preconceito. Por outro lado, a penhora do bem de família pode submeter o devedor a uma situação degradante, uma vez que suporta um ônus que não possui condições financeiras para arcar. Essa situação 
expõe um caso de difícil solução, pois envolve uma colisão de princípios constitucionais fundamentais, exigindo para a sua solução a ponderação entre os princípios.

A colisão ocorre quando, em uma circunstância específica, dois ou mais princípios dispõem de modo conflitante. No caso concreto, um princípio terá seus efeitos limitados em prol da aplicabilidade do outro princípio, porém, o princípio cuja aplicação foi afastada ou limitada não é inválido; ou seja, em um caso concreto distinto, o princípio anteriormente cedente poderá vir a prevalecer. Os princípios são mandamentos de otimização, e a sua colisão será resolvida na dimensão do peso, verificando, em cada caso, qual possui maior peso e, portanto, irá prevalecer (ALEXY, 2006, p. 93-94).

No atual cenário jurídico, por força da LC n. 150/2015, é inadmissível a penhora do bem de família do empregador para execução de dívida trabalhista da empregada doméstica. Contudo, conforme se depreende do estudo realizado, o legislador não apresentou nenhuma alternativa para substituir a penhora, acarretando um retrocesso aos direitos e garantias alcançados pelas trabalhadoras.

$\mathrm{O}$ mecanismo mais adequado para assegurar o crédito do trabalhador e resguardar o direito à moradia do empregador é a relativização do instituto jurídico da penhora. A medida de impenhorabilidade absoluta do bem de família mostra-se exagerada, desproporcional, pois à medida que coloca ricos e pobres, milionários e falidos em um mesmo patamar, acarreta demasiadas injustiças. A impenhorabilidade absoluta concede à mansão de um empregador a mesma proteção da residência do empregador de classe média, sem levar em consideração suas condições financeiras individuais e o valor econômico do bem de família (REDONDO, 2008, p. 7).

A relativização exige a análise do direito à moradia do empregador e da proteção à trabalhadora doméstica a partir do princípio da proporcionalidade e de seus subprincípios - adequação, necessidade e proporcionalidade em sentido estrito. $\mathrm{O}$ aplicador do direito deve verificar, por meio de um teste de proporcionalidade, se a medida da impenhorabilidade absoluta é proporcional, considerando-se os direitos fundamentais envolvidos no caso concreto.

O princípio da proporcionalidade possibilita ao intérprete do direito solucionar conflitos entre princípios constitucionais a partir da ponderação entre os valores constitucionais. Permite, ainda, aferir se os meios aplicados à limitação da aplicação de um princípio constitucional são válidos (MARMELSTEIN, 2013, p. 366). A Constituição não prevê norma específica acerca do princípio da proporcionalidade, contudo, mesmo ausente o reconhecimento expresso a essa norma, sua previsão pode ser induzida a partir da própria Carta de direitos fundamentais, uma vez que esse princípio possibilita a aplicação dos demais princípios constitucionais.

O princípio da proporcionalidade é necessário para conciliar os valores e interesses incompatíveis e contraditórios, expressos em forma de princípios que, diversamente, não deixariam ao aplicador do Direito outra solução que não a difícil decisão de afastar de modo absoluto um valor constitucional (GOMES, 2001, p. 162 - 
163). A medida que resulta na impenhorabilidade do bem de família na execução de dívida do trabalhador deve ser analisada a partir, portanto, do princípio da proporcionalidade.

A Lei n. 8.009/90 previu exceções à impenhorabilidade do bem de família, dentre as quais se encontrava a possibilidade da penhora do bem de família, quando necessária para assegurar a execução do crédito trabalhista da empregada doméstica. Posteriormente, a Lei Complementar n. 150/2015, pretendendo estabelecer uma isonomia da trabalhadora doméstica com os demais trabalhadores urbanos e rurais revoga essa previsão e torna o bem de família impenhorável, até mesmo para a garantia do pagamento das verbas trabalhistas devidas à empregada doméstica em uma execução judicial.

É contraditório, no entanto, que a proteção garantida pela Constituição Federal, pela EC n. 72/2013 e pela LC n. 150/2015 à relação de emprego da trabalhadora doméstica seja utilizada para se afastar um regra - a da penhorabilidade do bem de família para a execução do crédito trabalhista da empregada doméstica - que assegura uma garantia essencial aos direitos previstos por essas normas em razão da característica própria do trabalho doméstico, qual seja, o de realizar seu labor sem finalidade lucrativa para uma família. O emprego do teste de proporcionalidade à regra que exclui o bem de família como garantia de penhora em uma execução judicial dos créditos trabalhistas da empregada doméstica coloca essa discussão em termos constitucionais.

A primeira pergunta do teste da proporcionalidade trata da adequação da medida utilizada para excluir a penhorabilidade do bem de família para garantir o direito à moradia do empregador. Pergunta-se se o meio utilizado para restringir um princípio constitucional é adequado para concretização do seu objetivo, no caso, se a exclusão da penhora do bem de família na execução judicial do crédito trabalhista seria adequada para garantir a preservação do direito de moradia do empregador (GOMES, 2001, p. 164). Nesse prisma, constata-se que a impenhorabilidade do bem de família asseguraria o direito fundamental do empregador e seria, portanto, um meio adequado.

A segunda pergunta do teste da proporcionalidade trata da necessidade da medida considerada, ou seja, considera se a medida da exclusão da penhora do bem de família é a que resulta em menos restrições em relação a outro direito fundamental. A exclusão da penhora do bem de família é o único meio para garantir o direito de moradia do empregador, ou há outra medida capaz de alcançar o mesmo resultado, porém restringindo o direito à proteção do trabalho doméstico em menor medida? Este estudo sugere que a medida da exclusão da penhora do bem de família não se mostra como uma medida necessária, pois a medida da relativização da penhora seria igualmente adequada para proteger o direito à moradia do empregador, porém menos restritiva dos direitos da trabalhadora doméstica.

Conforme a medida da relativização da penhora, para assegurar a execução da dívida trabalhista da empregada doméstica em face do empregador que possui um único bem, preliminarmente dever-se-ia realizar 
uma consulta aos objetos que guarnecem o domićlio do empregador. Embora a Lei n. 8009/90, em seu artigo 1, Súnico, estabeleça que os bens que guarnecem o lar também sejam considerados bem de família, considera-se que a sua penhora não ameaçaria o direito à moradia do empregador e, portanto, seria medida razoável quando garantisse a execução. ${ }^{15}$ Encontrados objetos suntuosos, tais quais, móveis decorativos, eletrônicos, joias, dentre outros bens que são dispensáveis a uma vida digna, e considerados capazes de assegurar a satisfação do crédito trabalhista, far-se-á a penhora de tantos bens quantos bastem para o pagamento da integralidade da dívida ${ }^{16}$.

Após examinados o valor e a essencialidade dos bens móveis que guarnecem o lar, se, ainda assim, o devedor não possuir objetos capazes de oferecer como quitação à dívida e não dispondo o executado de outros bens para garantir o adimplemento das verbas trabalhistas, a relativização propõe que se faça uma avaliação do valor do bem de família e da renda de seus proprietários, concomitantemente a uma verificação do montante total da dívida.

Após a comparação entre os mesmos, analisa-se a possibilidade de, mediante a venda do imóvel e a quitação da dívida, ser possível a compra de outro imóvel que propicie ao antigo devedor e seus dependentes uma vida digna (REDONDO, 2008, p. 8). A relativização da penhora atenderia, assim, aos questionamentos da adequação e necessidade; enquanto a impenhorabilidade absoluta, apesar de adequada, não parece ser necessária para a proteção ao direito de moradia do devedor e, portanto, é medida desproporcional.

O teste da proporcionalidade pode se encerrar; porém, somente para fins de argumentação, examina-se a proporcionalidade em sentido estrito da medida da impenhorabilidade absoluta, em que busca identificar se a limitação de um direito fundamental em detrimento ao outro acarretou mais vantagens ou prejuízos. "Enquanto nos critérios anteriores, analisaram-se as condições fáticas para a aplicação de um princípio, observam-se agora suas condições jurídicas, de forma que as disposições de um princípio serão analisadas em relação às disposições do princípio conflitante, e, de acordo com a máxima da ponderação" (GOMES, 2001, p. 171).

Por um lado, a penhora de um bem de família poderá submeter o devedor a uma situação de necessidade, tendo em vista que, em razão de sua insuficiência econômica, não possui condições de prover o seu sustento, afetando sobremaneira o exercício de uma vida digna. Por outro, a penhora do único bem do devedor em prol da garantia do pagamento da dívida trabalhista possibilitaria à trabalhadora doméstica a efetivação de seus direitos, uma existência digna, uma vez que os valores recebidos em razão da expropriação do bem do seu antigo empregador constituiriam fonte de renda para prover seu sustento e de seus familiares. A proporcionalidade em sentido estrito considera se a medida da impenhorabilidade absoluta, ao assegurar proteção ao direito de moradia

\footnotetext{
${ }^{15}$ Nesse sentido, ver Recurso Especial No 1.066 .463 - SP (20080128951-8), Relatora: Ministra Eliana Calmon, Segunda Turma, Superior Tribunal de Justiça: "Interpretação sistemática que se faz do art. $1^{\circ}$ da Lei 8.009,90, juntamente com o CPC e a LEF, para proclamar a penhorabilidade de aparelhos de ar-condicionado, lava-louças, som, freezer e bar em mogno, bens úteis, mas não indispensáveis à família”.
} 
do empregador, não acaba por causar, desproporcionalmente aos benefícios alcançados, prejuízos à trabalhadora doméstica.

Marmelstein (2013, p. 376) estabelece que para se verificar a proporcionalidade em sentido estrito, devese observar se o resultado conquistado com a medida refutou direitos fundamentais mais relevantes aos quais se pretendia garantir. Percebe-se que a exclusão da penhora para garantir a solvência do crédito trabalhista por meio da execução judicial do bem de família assegura o direito do empregador à moradia, contudo, coloca a trabalhadora doméstica em uma condição precária e desumana, pois fica sem recursos para efetivar a proteção garantida pela própria Constituição. Apesar do recente avanço normativo, o trabalho doméstico é um tipo de atividade ainda marcadamente precária: baixa remuneração, alta informalidade, baixo nível educacional e pouca organização coletiva.

Ademais, como já ressaltado, diferentemente do empregado de uma empresa, que possui a possibilidade de levar outros bens à penhora, a empregada doméstica exerce sua atividade no âmbito residencial e encontra-se limitada aos bens de seus empregadores - particulares que usualmente só possuem um bem, o bem de família. A impenhorabilidade absoluta, nesse caso, cria um ônus insuportável para um grupo de trabalhadoras já extremamente vulneráveis. Portanto, tal medida também falha no que concerne à sua proporcionalidade em sentido estrito.

A revogação do inciso "I" do artigo $3^{\circ}$ da Lei n. 8009/90 parece ter criado uma lacuna no nosso ordenamento. O ideal é que o próprio legislador repare essa situação, adotando, por exemplo, uma regra que permita a relativização da penhora no caso de créditos trabalhistas da empregada doméstica. Enquanto isso não ocorrer, o intérprete constitucional, a partir de um raciocínio de proporcionalidade, deve permitir a relativização da penhora.

Por fim, não sendo possível a venda do bem de família e a compra de outra moradia com valor inferior, mas que apresente condições dignas, propõe-se adotar outros meios acessórios e subsidiários como forma de adimplir o crédito em mora. Já existe no Brasil um sistema criado pelo Tribunal Superior do Trabalho, por meio da Regulamentação Administrativa n. 1470, de 24 de agosto de 2011, que insere todos os empregadores insolventes, condenados em sentença judicial transitada em julgado ou que não tenham cumprido os termos estabelecidos em acordo judicial firmado na justiça, perante o Ministério Público do Trabalho ou mesmo estabelecido perante as Comissões de Conciliações Prévias, em um cadastro denominado de Banco Nacional de Devedores Trabalhista - BNDT.

No banco de dados, inserem-se todas as informações da pessoa física ou jurídica, de direito público ou privado, que estão em mora com as obrigações trabalhistas. A inserção do nome do empregador no sistema de

\footnotetext{
${ }^{16}$ Conforme Artigo 659 do Código de Processo Civil.
} 
empregadores inadimplentes enseja a restrição do seu crédito, tal como, o sistema de proteção ao crédito, constrangendo o empregador a realizar o pagamento da dívida trabalhista, para que somente depois seja retirado seu nome da lista de insolventes.

O empregador doméstico terá, assim, seu CPF inscrito com restrições no cadastro da Receita Federal, contendo informações a respeito do montante da dívida, bloqueio de valores, e do valor a ser penhorado para quitação da dívida. Adimplindo o devedor o débito, será expedida uma determinação judicial para a retirada do nome do insolvente do banco de dados e poderá esse emitir uma certidão que ateste a inexistência de débitos trabalhistas - CNDT.

A forma como o sistema desenvolve-se atualmente, contudo, não atende à satisfação do crédito da empregada doméstica, pois, como se denota, o cadastro é voltado para empresas ${ }^{17}$ comerciais, não incluindo atividades de fins não lucrativos, como a desenvolvida pela trabalhadora doméstica. Assim sendo, faz-se necessária uma adaptação ao BNDT, com o fim de atender a satisfação do débito trabalhista da doméstica.

Propõe-se que o BNDT apresente uma regulamentação específica para a trabalhadora doméstica e que, após a inclusão do empregador doméstico, pessoa física, o mesmo tenha absolutamente restrita a realização de transações comerciais, tal qual ocorre no Sistema de Proteção ao Crédito - SPC. Os Tribunais Regionais do Trabalho poderiam informar com habitualidade o valor da dívida ao banco de dados, bem como viabilizar a realização de consultas a respeito da existência de outros bens em nome do empregador - tal medida possui o condão de compelir o devedor a realizar o pagamento das verbas salariais.

\section{CONCLUSÃO}

A modificação da LC n. 150/2015 na revogação do inciso "I" do artigo $3^{\circ}$ da Lei n. 8.009/90, que exclui de sua previsão a possibilidade da penhora do bem de família para assegurar o pagamento de dívida trabalhista à empregada doméstica, acarretou um significativo retrocesso na evolução normativa da proteção ao trabalho doméstico. A trabalhadora passa a não ter qualquer mecanismo que viabilizasse o recebimento das verbas trabalhistas, quando seu empregador for proprietário de um único bem. A LC n. 150/2015 foi contraditória ao estabelecer direitos e garantias às trabalhadoras e, ao mesmo tempo, revogar medida essencial para possibilitar o pagamento de débitos trabalhistas.

A impenhorabilidade do bem de família em razão de dívidas trabalhistas estimula o empregador a descumprir as normas legais, ao calcular ser menos oneroso manter uma empregada em condições irregulares, tendo em vista que a inobservância dos direitos trabalhistas não lhe acarretará resultados gravosos. O resultado é a 
ineficácia da proteção legal, com o desrespeito aos direitos dessas trabalhadoras, que ao longo do tempo já suportaram tantos abusos.

A impenhorabilidade do bem se justifica em razão da preservação da moradia do empregador, por ser esse um direito fundamental, devendo assim lhe ser mantidas condições mínimas para uma vida digna. Contudo, não se pode olvidar que assim como o direito à moradia, a proteção aos direitos fundamentais da trabalhadora doméstica, dentre os quais a proteção ao salário, também encontra guarida no seio constitucional.

Diante desse conflito, necessário realizar uma ponderação acerca da aplicabilidade da medida da impenhorabilidade absoluta. A partir desse raciocínio, conclui-se que a medida da impenhorabilidade absoluta é adequada para proteger o direito à moradia do empregador, porém não é necessária. A relativização da penhora é igualmente adequada ao mesmo fim, porém mostra-se menos restritiva do direito à proteção do trabalho doméstico. Essa medida justifica-se diante das características e circunstâncias da trabalhadora doméstica. Não havendo outro bem na titularidade do empregador, que não seja o bem de família, o direito de satisfação ao crédito da trabalhadora restaria frustrado.

Portanto, no atual contexto jurídico, é imprescindível que se detenha especial atenção em torno desse assunto, estabelecendo medidas que possam assegurar o adimplemento das verbas trabalhistas e rescisórias da empregada doméstica, bem como evitar a prática de infrações às normas legais e a descrença do trabalhador na Justiça Trabalhista, visando assim, reprimir condutas que acarretem danos ainda maiores dos que os já suportados por essas trabalhadoras.

\title{
ATTACHMENT OF THE FAMILY HOUSE VERSUS EMPLOYER'S HOUSING RIGHT: THE CASE OF DOMESTIC WORKERS' LABOR CLAIMS
}

\begin{abstract}
The family house is an estate which is used by its owner, person or family, for residential purposes. To protect such property and movable properties, ensure a minimum standard of living and guarantee basic conditions for a dignified existence, Law 8009/90 instituted a de-attachment clause, making it impossible for such assets to be attached to servicing of debts in any possible judicial execution. However, Law 8009/90 provided, in its Article 3, a list of exceptions to immunity from seizure, including the possibility of attachment for the payment of labor debts of the employer to the domestic worker. The Complementary Law 150/2015 repealed this clause, which provided for an exception in favor of the domestic worker, without providing alternative measures to ensure the enforcement of the labor debt. Given the gaps left by the legislation, the domestic worker is even more vulnerable, because despite the new rights recognized by LC 150/2015, the worker does not have any guarantees regarding

\footnotetext{
${ }^{17}$ É de se perceber que o cadastro desenvolvido pelo TST é relevante, tendo em vista que empresas participantes de contratos de licitações não poderão concorrer enquanto integrarem o BNDT, em razão da necessidade da certidão negativa de dívida, que não poderão obter quando inclusos no sistema.
} 
the recovery of unpaid wages, for example. LC 150/2015 brought instability and insecurity to the labor contract of domestic workers. This paper develops a scientific research in order to reflect on the reasonableness of Article 46 of Complementary Law n. 150/2015 that repeals subsection "I" of Article 3 of Law n. 8009/90, considering, therefore, alternatives to protect workers' wage credits. This is a study of reflective-theoretical, explanatory and descriptive character, based on bibliographical and documentary research, in consultation of literature, jurisprudential and legislative sources.

Keywords: Family House; De-attachment Clause; Domestic Worker; Labor Credits; Right to Housing.

\section{REFERÊNCIAS}

ALEXY, Robert. Teoria dos Direitos Fundamentais. Tradução de: Virgílio Afonso da Silva. 2. ed. São Paulo: Malheiros, 2006.

BLACKETT, Adelle. The Decent Work for Domestic Workers Convention and Recommendation. American Journal of International Law, Washington D.C., v. 106, n. 3, p. 778-794, 2012.

BRASIL. Lei n. 8.009, de 29 de março de 1990. Dispõe sobre a Impenhorabilidade do Bem de Família. Diário Oficial [da] União, Brasília, DF, 30 mar. 1990. Disponível em: <http://www.planalto.gov.br/ccivil_03/leis/L8009.htm>. Acesso em: 20 ju. 2016.

CARDOSO, Adalberto; LAGE, Telma. As Normas e os Fatos: Desenho e efetividade de regulação do mercado de trabalho no Brasil. São Paulo: FGV, 2007.

CARLI, Ana Alice de. Bem de Família do Fiador e o Direito Fundamental à Moradia. 2008. 185 f.. Dissertação (Mestrado em Direito Público e Evolução Social), Universidade Estácio de Sá, Rio de Janeiro. Disponível em: $<$ http://portal.estacio.br/media/2476208/ana\%20alice\%20de\%20carli.pdf> Acesso em 01 dez. 2015.

COSTA, Joaze Bernardino. Sindicatos das Trabalhadoras Domésticas no Brasil: Teorias da descolonização e saberes subalternos. 2007. 287 f.. Tese (Doutorado em Sociologia), Universidade de Brasília, Brasília. Disponível em: < http://repositorio.unb.br/bitstream/10482/2711/1/2007_JoazeBernardinoCosta.pdf>. Acesso em 20 jul. 2016.

CZAJKOWSKI, Rainer. A Impenhorabilidade do Bem de Família: comentários à Lei 8.009/90. Curitiba: Juruá, 1994.

DIAZ-ORDAZ, Lisa. Real Work: Domestic Workers' Exclusion from the Protections of Labor Laws. Buffalo Journal of Gender, Law \& Social Policy, n.19, pp.107-145, 2010/2011.

GAMA, Guilherme Calmon Nogueira; MARÇAL, Thaís Boia. Penhorabilidade do Bem de Família "Luxuoso" na Perspectiva Civil-Constitucional. Revista Síntese de Direito de Famúlia, v.15, n.84, p.30-45, jun/jul., 2014.

GOMES, Ana Virgínia Moreira. A Aplicação do Princípio Protetor no Direito do Trabalho. São Paulo: LTr, 2001.

HONÓRIO, Cláudia. Penhorabilidade do Bem de Família do fiador e direito à moradia: uma leitura sistemática constitucional. Revista Forense, Rio de Janeiro, v. 104, n. 396, p. 25-59, mar/abr., 2008. 
INTERNATIONAL LABOUR ORGANIZATION - ILO. Domestic workers across the world: global and regional statistics and the extent of legal protection. Geneva: ILO International Labour Office, 2013.

JÚNIOR, Hermano Queiroz. Os Direitos Fundamentais dos Trabalhadores na Constituição de 1988. São Paulo: LTr, 2006.

MARCO, Cristhian Magnus de; BRANCO, Gerson Luiz Carlos. O Princípio da Proteção ao Salário sob a ótica dos Direitos Fundamentais. Revista Pensar, Fortaleza, v. 19, n. 2, p. 339-367, mai/ago., 2014.

MANTOUVALOU, Virginia. Human Rights for Precarious Workers: the Legislative Precariousness of Domestic Labour. UCL Labour Rights Institute Working Paper Series, 2012. Disponível em: $<$ www.ucl.ac.uk/laws/lri/papers/VM\%20precarious\%20workers.pdf >. Acesso em 28 de mar. 2016.

MANTOUVALOU, Virginia; ALBIN, Einat. "The ILO Convention on Domestic Workers: From the Shadows to the Light". Industrial Law Journal, v. 41, 2012. Disponível em: SSRN: <http://ssrn.com/abstract=1963104 . Acesso em 28 mar. 2016.

MARMELSTEIN, George. Direitos Fundamentais. 4. ed. São Paulo: Atlas, 2013.

MUNIZ, Mirella Karen de Carvalho Bifano. O Direito Fundamental ao Salário Mínimo Digno: uma análise à luz do Princípio da Dignidade da Pessoa Humana. Belo Horizonte: Pontifícia Universidade Católica de Minas Gerais, 2009.

NEETHA, Pillai; PALRIWALA, Rajni. The Absence of State Law: Domestic Workers in India. Canadian Journal of Women and the Law, Toronto, v. 23, n. 1, p. 97-119, 2011.

PIMPÃO, Rosemarie Diedrichs. O Direito Social à Moradia à Luz do Princípio da Dignidade da Pessoa Humana. Revista TRT-9aR, Curitiba, n. 64, p. 1-31, jan./jun., 2010.

QUEIROZ, Cristina. O Princípio da Não Reversibilidade dos Direitos Fundamentais Sociais: Princípios Dogmáticos e Prática Jurisprudencial. Coimbra: Coimbra Ed., 2006.

RAMIREZ-MACHADO, José Maria. Domestic work, conditions of work and employment: A legal perspective. 2003. Disponível em: <http://www.ilo.org/travail/whatwedo/publications/WCMS_TRAVAIL_PUB_7/lang-en/index.htm>. Acesso em: 22 de julho 2003.

REDONDO, Bruno Garcia. A (Im)penhorabilidade da remuneração do executado e do imóvel residencial à luz dos princípios constitucionais e processuais . Revista dialética de direito processual. São Paulo: Dialética, n. 63, p. 20-28, jun/2008.

REDONDO, Bruno Garcia; LOJO, Mário Vitor Suarez. Penhora. São Paulo: Método, 2007.

SANTOS JUNIOR, Adalmo Oliveira dos. O REGIME JURÍDICO DAS IMPENHORABILIDADES. Revista de Processo, São Paulo, v. 239, p.121-136, jan. 2015.

SARLET, Ingo Wolfgang. O Direito Fundamental à Moradia na Constituição: algumas anotações a respeito de seu contexto, conteúdo e possível eficácia. Revista de Direito Consumidor, São Paulo, n.46, p. 193-244, abr./jun., 2003. 
Dignidade da pessoa humana e direitos fundamentais na Constituição Federal de 1988. Porto Alegre: Livraria do Advogado, 2009.

SMITH, Peggie. Aging and Caring in the Home: Regulating Paid Domesticity in the Twenty-First Century. Iowa Law Review, Iowa City, v. 92, p.1835-1900, 2007.

Work like any Other, Work Like No Other': Establishing Decent Work for Domestic Service Workers. Employee Rights And Employment Policy Journal, Chicago, v. 15, n. 1, p.159-200, 2011.

Trabalho enviado em 18 de abril de 2017.

Aceito em 25 de agosto de 2016. 